\title{
Oświata i szkolnictwo na łamach czasopism: „Przegląd Diecezjalny”, „Kielecki Przegląd Diecezjalny" w latach 1911-1939
}

Kielce swoim początkiem sięgają XI w. Pierwsze wzmianki pochodzą z $1081 \mathrm{r}$. W 1364 r. Kielce stały się miastem, stanowiły własność biskupów krakowskich. Na początku XIII w. (pomiędzy 1208 a 1218 r.) powstała przy kolegiacie szkoła parafialna. Wśród wychowanków szkoły znalazł się m.in. dominikanin Wincenty z Kielc. W 1364 r. nadano Kielcom prawa magdeburskie. W 1496 r. kardynał Fryderyk Jagiellończyk nadał miastu herb - złote litery CK w koronie na czerwonym tle będące skrótem od łacińskiego Civitas Kielcensis. Począwszy od XV w. mieszkańcy otrzymywali liczne przywileje m.in. zezwolenie na organizację trzech jarmarków i cotygodniowych targów¹.

W czasie najazdu szwedzkiego miasto doszczętnie spłonęło. Usuwanie zniszczeń okazało się dużym wyzwaniem - z wielkich pożarów ocalały jedynie pałac, katedra i klasztor na wzgórzu Karczówka. Wybudowano seminarium duchowne, szkołę średnią, teatr, browar, szpital sióstr miłosierdzia oraz istniejące do dziś kamienice na Rynku. Działalność rozpoczęła kopalnia wapienia na Kadzielni oraz dwie cegielnie. Obok pałacu biskupów wzniesiono stajnie, wozownie i szkołę jazdy konnej zwaną rajszulem. Ludność miasta wzrosła do ponad 2000. Powstały nowe domy i ulice².

Po III rozbiorze Polski miasto zostało włączone do zaboru austriackiego. Kielce stały się stolicą cyrkułu (powiatu) ze starostą na czele podległym bezpośrednio władzom krajowym we Lwowie. Jako język urzędowy wprowadzono niemiecki³.

* Dr, Zakład Literatury i Kultury Języka, Instytut Edukacji Szkolnej, Wydział Pedagogiczny i Artystyczny, Uniwersytet Jana Kochanowskiego, 25-029 Kielce, ul. Krakowska 11.

1 J. P a z d u r, Dzieje Kielc do 1863 roku, Wrocław 1967, s. 12-88.

2 Tamże, s. 138-149.

3 Tamże, s. 182-190. 
W wyniku ustaleń kongresu wiedeńskiego w 1815 r. ziemia kielecka przypadła rosyjskiemu zaborcy. W 1816 r. Kielce stały się siedzibą władz województwa krakowskiego. Dzięki staraniom Stanisława Staszica w 1816 r. utworzono tutaj pierwszą wyższą uczelnię techniczną w Polsce - Szkołę Akademiczno-Górniczą. Powstały prywatne szkoły żeńskie, księgarnia i drukarnia. W 1834 r. oddano do użytku szosę biegnącą przez centrum miasta, łączącą bezpośrednio Kielce z Warszawą i Krakowem. Nastąpiło znaczne ożywienie kulturalne, studenci zaczęli organizować tajne związki „burszów i szpaków”, starsi kielczanie interesowali się lożami masońskimi .

Wskutek powstania listopadowego rozwój Kielc został gwałtownie zahamowany. Na miejsce województwa utworzono gubernię ${ }^{5}$.

W 1845 r. w związku z carską reformą administracyjną zlikwidowano gubernię kielecką. Kielce stały się miastem powiatowym w guberni radomskiej. Nie inwestowano w rozwój przemysłu. Powoli malała także liczba mieszkańców. Wraz z odpływem urzędników do Radomia wyjechali również kupcy, rzemieślnicy, uczniowie i kadra nauczycielska.

W okresie powstania styczniowego do walki z zaborcą oprócz kleru przystąpiła też kielecka młodzież. W 1867 r. reaktywowano kielecką gubernię z wydzielonej radomskiej. Otwarte zostało progimnazjum żeńskie przekształcone w 1883 r. w gimnazjum.

Na początku XX w. istniało w Kielcach 17 miejskich szkółek elementarnych, kilka szkół prywatnych, gimnazjum żeńskie. Po okresie strajków w 1905 r. nastąpił w Kielcach rozwój szkół handlowych. Od 1909 r. zaczęła również funkcjonować średnia szkoła górnicza ${ }^{6}$.

W 1915 r. założono Komisję Szkolną, która powoływała do istnienia szkoły miejskie. Jeśli chodzi o szkolnictwo średnie, to istniały: handlowa męska, handlowa żeńska, trzy gimnazja prywatne ${ }^{7}$.

Po utworzeniu na terenach centralnej Polski Generalnego Gubernatorstwa Kielce zdegradowano do roli stolicy powiatu w dystrykcie radomskim. Wkroczenie wojsk niemieckich do miasta niemal całkowicie sparaliżowało życie społeczne.

Historia kieleckich czasopism sięga wieku XIX. Można ją podzielić na cztery okresy: lata niewoli narodowej, dwudziestolecie międzywojenne, druga wojna światowa, okres po drugiej wojnie światowej. Ich rozwój ściśle wiązał się z dziejami prasy urzędowej Księstwa Warszawskiego i Królestwa Kongresowego ${ }^{8}$.

I tak, 2 października 1870 r. ukazał się pierwszy numer „Gazety Kieleckiej”. Było to jedno z najstarszych pism regionalnych o charakterze informacyjnym. Ukazywało się dwa razy w tygodniu, w środy i w soboty. Także w tym roku rozpoczęli działalność redaktorzy periodyku „Pamiętnik Kielecki”. Zawierał on artykuły o tematyce historyczno-krajoznawczej.

${ }^{4}$ Tamże, s. 191-193, 207-208.

${ }^{5}$ Tamże, s. 226-228.

6 J. P a z d u r, Dzieje Kielc 1864-1939, Wrocław 1971, s. 61-64.

7 Tamże, s. 122.

${ }^{8}$ M. A d a m c z y k, Cztery epoki prasy Kielecczyzny 1811-1956, Kraków-Kielce 1990, s. 10, 18. 
Po Il wojnie światowej wydawano dzienniki: od 1949 r. „Słowo Ludu” oraz od 1971 r. „Echo Dnia”.

Równolegle z prasą świecką rozwijała się także prasa katolicka. Miało to zapewne związek z erygowaniem w 1905 r. diecezji kieleckiej. „Najpopularniejszą była "Gazeta Świąteczna», posiadająca licznych korespondentów w diecezji i regularnie informująca swych czytelników o bieżących wydarzeniach kościelnych i społecznych”. W mniejszym stopniu docierała do Kielc „Zorza”, „Słowo” czy „Pola” ${ }^{10}$. Większą popularność zdobył „Przegląd Katolicki”. Gazeta ta została w 1863 r. przekształcona przez ks. Michała Nowodworskiego z czasopisma „Pamiętnik Religijno-Moralny”11. „Przegląd Katolicki” ukazywał się raz w tygodniu. Obok wymienionych w 1911 r. zaczęto wydawać „Przegląd Diecezjalny”. Pierwszy numer ukazał się 1 października 1911 r. Redaktorem i równocześnie wydawcą był ks. Jacek Pycia - profesor Kieleckiego Seminarium Duchownego. Czasopismo będące jego organem urzędowym, poświęcono także sprawom duchowieństwa diecezji kieleckiej. W 1925 r. zmieniono tytuł czasopisma na „Kielecki Przegląd Diecezjalny", który z niewielkimi przerwami ukazuje się do dziś'12. Czasopismo dzieliło się na dwie części:

- część urzędowa, w której zamieszczano m.in. wiadomości z Konsystorza Kieleckiego, rozporządzenia rządowe;

- część nieurzędowa z artykułami o treści społecznej, politycznej, gospodarczej i kulturalnej.

Na łamach „Przeglądu Diecezjalnego”, cytując za Moniką Marcinkowską, „znajdziemy materiały odnoszące się do wszystkich funkcji kapłanów. Są nimi funkcja nauczycielska, kapłańska, królewska. Funkcja nauczycielska realizowana była poprzez kazania, misje parafialne, rekolekcje, prace katechetyczną. Do drugiej należało administrowanie sakramentów, a zwłaszcza Eucharystii i pokuty. Trzecia obejmowała między innymi kierownictwo duchowe kapłana względem powierzonych mu wiernych oraz zaangażowanie społeczne duchowieństwa. Niektóre z zamieszczonych artykułów mają charakter normatywny, określające zasady i sposoby wykonywania tych funkcji. Do tej grupy zaliczyć należy dokumenty Stolicy Apostolskiej, dekrety i wykładnie prawa kanonicznego dokonywane przez urzędy watykańskie, wystąpienia episkopatu, listy pasterskie, okólniki, zarządzenia kurii diecezjalnej czy władz państwowych odnoszące się do spraw związanych z niektórymi czynnościami pasterskim"13.

${ }^{9}$ A. S z a fa r s k i, Teologia pastoralna w diecezji kieleckiej w XIX w. „Nasza Przeszłość”. Studia z dziejów Kościoła i kultury w Polsce, t. 57, Kraków 1982, s. 49.

10 Tamże, s. 49-50.

11 Tamże, s. 75.

${ }^{12}$ A. K a le t a, Piśmiennictwo księży profesorów Seminarium Kieleckiego. Zarys problematyki, [w:] Kultura teologiczna Seminarium Duchownego w Kielcach 1727-2002. Księga Jubileuszowa, red. D. O I s z e w s k i, R. Ku l i g o w s k i, K. G u r d a, Kielce 2002, s. 435.

${ }^{13}$ M. M a r c i n k o w s k a, „Kielecki Przegląd Diecezjalny” jako forum prezentacji poglądów na temat roli duchowieństwa we wspólnotach lokalnych (okres dwudziestolecia międzywojennego), [w:] Duchowieństwo polskie w latach niepodległości 1918-1939 i w okresie Il wojny światowej, red. J. G a p y s, M. B. M a r kow s k i, Kielce 2006, s. 11-12. 
Ponieważ jedną z funkcji kapłana była funkcja nauczyciela, stąd w czasopiśmie znalazły się artykuły związane z problemami oświaty i wychowania. Dużo miejsca poświęcono nauce religii w szkole, edukacji młodzieży dorosłej czy współpracy księży z nauczycielami. Liczne publikacje dotyczyły praktyk religijnych młodzieży, wychowania młodych chłopców, a także kursów katechetycznych czy pracy charytatywnej. Od 1930 r. na łamach czasopisma ukazywał się cykl artykułów poświęconych nowoczesnym prądom w szkole polskiej. Rzetelnie i skrupulatnie omówiono w nich:

- rodzaje szkół i ich funkcjonowanie w Polsce i na świecie,

- plusy i minusy kształcenia koedukacyjnego,

- sylwetkę ideału młodego człowieka,

- wychowanie społeczne, rodzinne.

Autorem niemal wszystkich artykułów tego cyklu był ks. Michał Klepacz (1893-1967), biskup łódzki, teolog, filozof, pedagog, profesor Kieleckiego Seminarium Duchownego i Uniwersytetu Wileńskiego ${ }^{14}$.

W 1921 r. w zeszycie 7. „Przeglądu Diecezjalnego” ks. Klepacz zamieścił ciekawy artykuł pt. My a szkoła dotyczący charakterystyki szkół podstawowych na świecie i w Polsce. Główną uwagę zwrócił na proces nauczania religii. Dlatego też szkoły te podzielił na:

1. bezwyznaniową,

2. międzywyznaniową,

3. wyznaniową.

Szkoła bezwyznaniowa była szkołą świecką. Cieszyła się dużym uznaniem wśród społeczności żydowskiej. Również w Polsce znajdowała się spora liczba osób opowiadająca się za taką szkołą, gdyż nie było w niej miejsca dla lekcji religii. Jak pisał autor: „Zaciętymi zwolennikami szkół niereligijnych są Żydzi wraz ze swą ekspozyturą: masonerią i socjalizmem... I u nas socjaliści walczą o tego rodzaju szkołę: uchwalenie Konstytucji stanowiło dla nich okazję do tej kwestii. Rozumie się, że ze względów zasadniczych musimy wystąpić przeciwko tak rozumianej szkole świeckiej"15.

W szkole międzywyznaniowej organizowano lekcje religii dla każdej grupy wyznaniowej dzieci osobno. Było ona obowiązkowa. Autor stwierdzał: „Drugim niebezpieczeństwem, grożącym ze strony szkoły symultatywnej jest, zwłaszcza u nas, możliwość zupełnego zalania szkół przez Żydów. Pomimo to społeczeństwo nasze, od dawna przyzwyczajone do tego typu szkolnictwa, nie widzi czy nie chce zdać sobie racji z groźnych skutków oparcia wychowania przyszłych pokoleń na szkole międzywyznaniowej"16.

Z kolei edukacja w szkole wyznaniowej opierała się na czterech podstawowych regułach:

a. „Wszystkie przedmioty są wykładane bez naruszenia żadnego z przekonań ani uczuć katolickich dzieci i dalej z takim poglądem na rzeczy, jaki mieć może uczony, ale wierzący katolik. Konsekwentnie i podręczniki muszą podlegać temuż samemu prawu,

14 Klepacz Michat, [w:] Bibliografia piśmiennictwa profesorów Seminarium Kieleckiego 1727- 2001. Księga jubileuszowa, oprac. D. K r z e ś n i a k-F i r l e j, W. F i r l e j, A. K a l e t a, Kielce 2001, s. 64.

${ }^{15}$ M. K I e p a c z, My a szkoła, „Przegląd Diecezjalny” [dalej: PD] 1921, z. 7, s. 138.

16 Tamże, s. 138. 
b. Całe etyczne prowadzenie uczniów, pobudki, jakimi się na nich działa, praktyki, do których są zaprawiani, są oparte na etyce katolickiej,

c. Są przyjmowane dzieci jednego tylko wyznania,

d. Nauczyciel jest tego samego wyznania co i dzieci"17.

W dalszej części pracy autor podał argumenty za powoływaniem szkół wyznaniowych jako jedynie słusznych. Twierdził, że kształcenie dzieci powinno być oparte na naukach chrześcijańskich.

Jak wcześniej wspomniano dużo uwagi poświęcano również wzajemnym relacjom księży i nauczycieli. Do obowiązków kapłana należało m.in. udzielanie wsparcia, pomocy, utrzymywanie przyjacielskich stosunków z nauczycielami. W „Przeglądzie Diecezjalnym” z 1921 r. w 9. zeszycie czytamy:

„Niemałą troską proboszcza być powinna myśl ułożenia swego stosunku do nauczycielstwa w parafii tak, aby wpływy nauczycielstwa utrzymywać na właściwym torze i we właściwym kierunku.

Niejeden proboszcz zdążył się przekonać, ile to szkody wyrządzi nauczyciel, jeżeli nie przejąwszy się chrześcijańskim duchem swego zaszczytnego powołania wychowawczego, zgubnie oddziaływa na młodzież i na starszych, odciągając ich od zasad chrześcijańskich na bezdroża ludowcowe i socjalistyczne pod hasłami fałszywego postępu..."18.

Z podręczników do lekcji religii najczęściej wymieniano Pogadanki ks. Młynarczyka, Chrystus w duszy dziecka ks. Gralewskiego lub Nauki wiary i moralności księdza Makłowicza. W starszych klasach używano m.in. podręczników księży Gadowskiego, Naskręckiego czy Baranowskiego.

W 1924 r. odbył się II Diecezjalny Zjazd Księży Prefektów w Kielcach. Jeden z omawianych punktów dotyczył praktyk religijnych młodzieży, przede wszystkim ich uczestnictwa w nabożeństwach szkolnych. Były one obowiązkowe, duchowni zachęcali, aby młodzież włączała się gorliwie w śpiew czy modlitwę. Wysłuchano także referatu księdza Sobczyńskiego pt. O harcerstwie. Autor pokazał, że jest to jedna z form współpracy z młodzieżą potrzebna do ogólnego jej rozwoju, tak chłopców, jak i dziewcząt. Stąd też apelował, aby księża chętnie uczestniczyli w działalności drużyn harcerskich w szkołach.

Zagadnieniem, do którego dość często powracano na łamach przeglądu było wychowywanie dzieci przez rodziców. W publikacjach skupiano się głównie na wytykaniu błędów, które popełniali rodzice. Wśród nich dość często pojawiały się wady rodziców, a nawet gorszące przykłady z ich strony. Najistotniejsze to: brak wychowania dzieci w duchu chrześcijańskim, brak autorytetu moralnego rodziców, częste kłótnie w domu, spożywanie przez dzieci alkoholu. Dlatego też duchowni pokazali, jak powinno wyglądać życie rodzinne. Przede wszystkim należało przestrzegać zasad religijnych, często wspólnie się modlić i uczestniczyć w nabożeństwach ${ }^{19}$.

17 Tamże, s. 139.

${ }_{18}$ A. S o b c z y ń s k i, Stosunek proboszcza do nauczycielstwa, „Przegląd Diecezjalny” 1921, z. 9, s. 191.

${ }^{19}$ B. R y d z y, Braki wychowania domowego i wpływ duszpasterza na rodziców, „Kielecki Przegląd Diecezjalny" [dalej: KPD] 1933, z. 10, s. 243-249; t e n ż e, Braki wychowania domowego i wpływ duszpasterza na rodziców. (Ciąg dalszy). Oddziaływanie duszpasterza, tamże, z. 11, s. 277-285. 
Z zagadnieniem tym wiązało się także przygotowanie dzieci do pierwszej spowiedzi i komunii świętej. Księżą dużą celowość widzieli we współpracy z rodzicami. Autor artykułu zauważył, że: „, Każdy duszpasterz wie i rozumie doskonale, jak ważną jest dla urobienia dusz młodzieży dobrze odbyta pierwsza spowiedź i Komunia. Niestety, nie chcą tego dostatecznie zrozumieć lub za mało rozumieją rodzice, a mianowicie nie doceniają, jakie wychowawcze znaczenie mają w życiu dziecka I spowiedź i I Komunia św."20

Sporo miejsca i uwagi na łamach „Kieleckiego Przeglądu Diecezjalnego” poświęcono również edukacji młodzieży dorosłej. Główny nacisk położono na ich uczestnictwo w naukach przedmałżeńskich: „Młodzież zarówno męska jak i żeńska, gdy dojdzie do wieku, w którym może powziąć zamiar zmiany stanu, należy wezwać na nauki" ${ }^{21}$. W artykułach starano się pokazywać, że nauki dla młodzieży dorosłej były bardzo ważne, gdyż przyczyniały się do życia według dekalogu.

Interesujący artykuł przedstawił Salezjanin ks. Alojzy Ciechorski w zeszycie 6-7 „Kieleckiego Przeglądu Diecezjalnego” z 1927 r. Podjął on temat kształcenia chłopców w oratoriach - zakładach salezjańskich. Swój początek wzięły one od założyciela zakonu Salezjanów - Świętego Jana Bosko. Tak oto o organizacji i prowadzeniu oratorium pisał autor: „Niema żadnego przymusu uczęszczania do oratorium. Młodzież przyciągamy środkami ubocznymi. Nie brakuje atoli pewnej kontroli i nagród dla zachęty... Środkami przyciągającymi są: obszerny dziedziniec do biegania, do ćwiczeń fizycznych; różne gry, jako to: kręgle, piłka, huśtawki, karuzel, gigant, loteria z darowanymi losami dla pilniejszych; dla starszych bilard; śniadania, cukierki, podwieczorki; dalej przechadzki dla wszystkich razem, albo z osobna dla oddziałów starszych lub lepiej zasłużonych; oprócz tego budujące przedstawienia amatorskie, kinematograf, wieczorki naukowe, muzyka, gimnastyka, korepetycje dla studentów, biura pracy, wypożyczalnia książek, popisy katechizmowe i sportowe, doroczne nagrody dla chłopców wzorowszych i pilniejszych; starsi korzystają z lokalów czytelnianych, z sal posiedzeń i gier towarzyskich, właściwych ich wiekowi; nadto mogą należeć do kasy wzajemnej pomocy i innych organizacji społecznych"22. Oprócz wyżej przytoczonych wychowawcy dysponowali także środkami, które pobudzały do większej pobożności. Były to: nabożeństwa, ubiory, ozdoby świąteczne, strojenie podwórka, przygotowywanie zaproszeń, kazania stosowane do wieku młodzieży z budującymi przykłada$\mathrm{mi}$, stowarzyszenia religijne ze statutami. Jako najskuteczniejszą metodę autor wymienił cechy, którymi winien okazać się wychowawca: dobroć, życzliwość, uprzejmość, cierpliwość oraz poświęcanie uwagi wychowankom. Podsumowując, ks. Ciechorski podkreślił, że oratoria były wręcz niezbędne w wychowywaniu chłopców młodszych i starszych.

Z analizy źródeł wynika, że najobszerniejszą część publikacji na temat oświaty i wychowania stanowiło zagadnienie Duchowieństwo wobec nowoczesnych

${ }^{20}$ Czynny udział matek i ojców przy przygotowywaniu dzieci do I spowiedzi i komunii św., KPD 1929, z. 4, s. 120.

${ }^{21}$ Nauka z młodzieżą dorosłą, KPD 1926, z. 5, s. 89.

${ }^{22}$ A. C i e chor ski, Duszpasterska praca nad chłopcami w parafii salezjańskim sposobem, KPD 1927, z. 6-7, s. 125. 
prądów w szkole polskiej. Jego autorem był wymieniany już ks. Michał Klepacz. Na początku cyklu autor odniósł się do stanowiska księży wobec problemów edukacji. Jak wiadomo głównym zadaniem szkoły było uczyć i wychowywać. W tym miejscu przytoczone zostały słowa ówczesnego ministra oświaty Stanisława Grabskiego na temat szkolnictwa: „Dotychczasowy rozwój oświaty był istotnie przede wszystkim ekspansją ilościową, teraz zaś trzeba osiągnięte rezultaty, istniejące programy i metody nauczania poddawać krytycznej rewizji i przystąpić do ustalenia rzeczywistego programu wychowania narodu...

Zadaniem ministerstwa oświaty musi się stać wychowanie typu obywatela, zdolnego zapewnić Polsce siłę, bezpieczeństwo i należne w świecie cywilizowanym stanowisko...

Ministerstwo nie może być tylko urzędem do zakładania szkół i kształcenia nauczycieli, ale musi stworzyć warunki do wychowania potrzebnego Polsce typu obywatela..."23. Edukacja i wychowanie to także jeden z celów kościoła, stąd dużo miejsca poświęcono również religijnemu wychowaniu dzieci i młodzieży. Cytując za księdzem Klepaczem: „Jeśli więc wychowanie musi się oprzeć na religii, a szkoła na naczelne stanowisko wysuwa wychowanie, stąd wniosek jasny, że duchowieństwo jako stróż moralności, opartej na dogmacie chrześcijańskim musi brać czynny udział w szkole czyli zainteresować się bliżej i głębiej zagadnieniami, odnoszącymi się do szkolnictwa"24.

W zeszycie 11. z roku 1929 „Kieleckiego Przeglądu Diecezjalnego” ksiądz Klepacz przedstawił statystkę szkolnictwa w Polsce oraz charakterystykę Związku Nauczycielstwa Polskiego. W tym czasie istniało 796 szkół średnich, 19 szkół wyższych, 1617 szkół zawodowych, 1430 przedszkoli, ok. 27 tys. szkół powszechnych. Ogólna liczba nauczycieli szkół powszechnych wynosiła ok. 70 tys. Dokonując zestawienia, ks. Klepacz wyrażał obawy o przyszłość edukacji. Wynikały one z szybkiego przyrostu naturalnego dzieci oraz małego budżetu przeznaczanego na rozwój szkolnictwa. Omawiając Związek Nauczycielstwa Polskiego, przedstawił jego działalność oraz cele. Analizując organizacje nauczycielskie, wykazał m.in., że przeciwstawiały się one uczeniu religii w szkołach, członkowie nie wykazywali chęci współpracy z duchowieństwem. Na koniec swoich rozważań odniósł się do fragmentu z broszury List do nauczycieli w sprawie szkoły antyreligijnej Artura Górskiego. Górski zawarł w nim następujące tezy:

1. „Religia stoi w sprzeczności z nauką, ponieważ [...] Kościół występował przeciw Kopernikowi, Galileuszowi i innym. Dziś zwalcza Einsteina, Darwina.

2. Kościół jest czynnikiem politycznym w życiu, a występuje zawsze w obronie umocnionej władzy. Dlatego Kościół jest czynnikiem wrogim dla mas pracujących. Stąd właśnie płynie szkodliwa rola religii w szkole. Jeżeli więc nie będzie religii w nauczaniu szkolnym, pozbędziemy się wpływu kleru na dzieci. Ale to tylko początek walki. Przecież wpływy religijne sięgają domu, rodziny; spotykamy się z nimi iw literaturze. Stąd konieczność szkoły antyreligijnej, aby mogła wystąpić w czynny stan walki [...] Środki do tej walki są następujące:

${ }^{23}$ M. K I e p a c z, Duchowieństwo wobec nowoczesnych prądów w szkole polskiej. Potrzeba zainteresowania się szkołą, KPD 1929, z. 10, s. 244.

${ }^{24}$ Tamże, s. 247. 
1) Przy każdym przedmiocie w szczególności przy fizyce, przyrodzie zwalczać religię.

2) Wykazywać wrogi stosunek do uczonych i nauki np. Kopernika i innych.

3) Przy pogadankach krajoznawczych np. gdzie można poruszyć architekturę kościołów, nie zapomnieć o fakcie, że w kościołach średniowiecznych były obliczenia akustyczne takie, aby stojąc gdzieś na drugim końcu kościoła, można było podsłuchać odbywającej się w konfesjonale spowiedzi.

4) To samo czynić na lekcjach języka polskiego: dyskredytować wobec dzieci te dzieła literackie, które uznają świętości religijne i narodowe [...]”25.

List ten został przedstawiony na konferencji pedagogicznej w Warszawie. Po jego wysłuchaniu większość nauczycieli opowiedziała się za tworzeniem szkół antyreligijnych.

Mając na uwadze powyższe stwierdzenie, w następnych numerach czasopisma ks. Michał Klepacz z dużą starannością przedstawił argumenty za nauką religii w szkole czy chrześcijańskim wychowywaniem dzieci.

Swoją polemikę rozpoczął od przedstawienia reformy szkolnej w szkole jednolitej. Zakładała ona likwidację trzech klas gimnazjum i wprowadzenie ośmioklasowej szkoły powszechnej, która miała być bazą dla całej edukacji. Za szkołę jednolitą autor uważał: „Szkoła jednolita to „ujednostajnienie szkoły” tak, aby niższy stopień był podbudową do wyższego; czyli aby była jedyna szkoła (od elementarnej do uniwersytetu) łatwo dostępna dla wszystkich.

Realizacją praktyczną tego postulatu byłaby szkoła państwowa, bezpłatna: siedmioletnia powszechna (dla wszystkich, a nie jak obecnie dla ludu); pięcioletnie gimnazjum, do którego dziecko przechodziłoby automatycznie ze szkoły powszechnej, i uniwersytetu.

Wobec tego pierwszym zadaniem tak pojętej reformy ma być skasowanie pierwszych trzech klas gimnazjalnych i zastąpienie ich trzema ostatnimi klasami szkoły powszechnej. Czyli szkoła powszechna ma być podstawą dla całego szkolnictwa"26.

Ks. Klepacz przeciwstawiał się także monopolowi szkolnemu. Jak podkreślał, w procesie wychowania powinni brać równy udział rodzice, szkoła i kościół. Nie należało tego obowiązku powierzać jedynie szkole, gdyż tam, gdzie rząd próbował wprowadzać monopol szkolny, tam zazwyczaj powstawały szkoły antyreligijne. We wniosku napisał: „W szkole, która ma prawdziwie wychowywać i porządnie uczyć, muszą mieć wpływy wszystkie te czynniki, które z racji swej natury i powołania mają przyczyniać się do wychowania człowieka cnotliwego, dzielnego obywatela, myślącego kategoriami państwowymi, narodowymi i ogólno ludzkimi, a więc rodzice (społeczeństwo), państwo i Kościół. Innymi słowy: Monopol szkolny byłby niesprawiedliwy, a nawet szkodliwy"27.

25 Tamże, s. 290-291.

${ }^{26}$ M. K I e p a c z, Duchowieństwo wobec nowoczesnych prądów w szkole polskiej. „Szkoła jednolita", a reformy szkolne, KPD 1930, z. 1, s. 25.

27 Tamże, s. 66. 
W kolejnych publikacjach Klepacz nawiązywał do artykułu z 1921 r. My a szkoła. Jeszcze raz odniósł się do szkoły wyznaniowej, szkoły bezwyznaniowej, która ,jest tylko wstępem do szkoły antyreligijnej” i szkoły antyreligijnej.

Ważnym czynnikiem w procesie wychowania była również koedukacja, czyli „wspólność nauczania i wychowania dziewcząt i chłopców przez nauczycieli obojga płci”. Z podjętej dyskusji nad koedukacją duchowni stwierdzili, że wspólna nauka w wieku dojrzewania nie powinna mieć miejsca. Dlatego też przeciwstawili się oni klasom koedukacyjnym.

W czasopiśmie został również przedstawiony ideał wychowania dzieci i młodzieży w szkole polskiej. Podobnie jak przy omawianiu monopolu szkolnego, tak i w tym miejscu wymieniono jako głównych przedstawicieli ideału wychowawczego dzieci i młodzież, rodzinę, państwo i Kościół. Aby osiągnąć ideał, każdy człowiek powinien posiadać odpowiednie cechu charakteru. Zaliczano do nich:

- czynną postawę wobec życia zewnętrznego, z którą wiązało się wychowanie fizyczne,

- ogólne wyrobienie duchowe,

- ideę jako środek wyrobienia charakteru.

Istnienie powyższych nie mogło mieć miejsca bez rozwijania rozumu: „Jeżeli umysł jest tylko kliszą fotograficzną, wówczas nie rozwijają się inne siły człowieka: jak wyobraźnia, ta nitka, jak ją nazywają, myśli, sąd własny itp. jeżeli natomiast zdobywamy wiedzę drogą własnego, możliwie samodzielnego wysiłku, wówczas umysł nasz osiąga jasność sądu i myślenia, spostrzegawczość, zdolność do obiektywnego badania i oceny zjawisk. W ten właśnie sposób rozwija się inteligencja człowieka, ten arcyważny warunek do tego, by być dobrym, jak również hartuje się wola... Stąd ten ważny postulat należy uwzględnić przy kształceniu dziecka. Szkoła więc powinna tak rozwijać umysł, by go przygotować do czynnego życia"28.

Równie ważnymi cechami były wola i emocje. Tak więc, można stwierdzić, że ideałem polskiej szkoły stało się wyrobienie osobowości człowieka świadomego swych celów, w sposób czynny uczestniczącego w życiu, ciągle pracującego nad własnym charakterem poprzez praktykowanie cnót. Podstawą wychowania społecznego było wychowanie indywidualne. Z kolei wychowanie społeczne odgrywało znaczącą rolę $w$ ideale wychowania państwowego, polegającego na „rozwoju świadomości i siły narodowej, kierowaniu wysiłków ku wyrabianiu najcenniejszego skarbu państwa: charakterów mocnych i prawych"29.

Kolejne artykuły mówiły o kształceniu i wychowaniu dorastającej młodzieży. Jako niezbędny element edukacji oprócz nauki religii autor - ksiądz Stanisław Borowiecki - wymienił również organizacje katolickie, prasę, biblioteki parafialne, domy parafialne. Ciekawostką było zamieszczenie w kieleckim przeglądzie w zeszycie 11. z roku 1934 rozporządzenia państwowego dotyczącego kwalifikacji

${ }^{28}$ M. K I e p a c z, Duchowieństwo wobec nowoczesnych prądów w szkole polskiej. Wychowanie charakteru jako ideał wychowania indywidualnego i społecznego. Ideał wychowania charakteru indywidualnego, tamże, z. 11, s. 300.

${ }^{29}$ Te nż e, Duchowieństwo wobec nowoczesnych prądów w szkole polskiej. Wychowanie Społeczne (narodowo-państwowe), tamże, z. 12, s. 335. 
zawodowych wychowawczyń przedszkola. Było to rozporządzenie Prezydenta Rzeczpospolitej Ignacego Mościckiego z dnia 27 października 1933 r. Czytamy w nim m.in.:

„Art.1. Kwalifikacje zawodowe do prowadzenia zajęć wychowawczych w przedszkolach posiada osoba, która uzyskała dyplom na wychowawczynię przedszkoli przez ukończenie państwowego lub prywatnego z prawami szkół państwowych: seminarium lub liceum dla wychowawczyń przedszkoli...

Art.7. Kwalifikacje zawodowe wychowawczyń przedszkoli uprawniają do prowadzenia zajęć wychowawczych w języku polskim..." ${ }^{30}$.

Po analizie niniejszych publikacji należy stwierdzić, że w omawianym okresie tj. w latach 1911-1939 sprawy oświaty i wychowania zajmowały wśród kieleckich duchownych bardzo ważną i znaczącą rolę. Główny nacisk kładli na wychowanie dzieci i młodzieży w duchu chrześcijańskiej nauki, prawd wiary i zasad religijnych. Należy zauważyć, że większość artykułów miała charakter praktyczny. Księża omawiali dokładnie zagadnienia, dawali wskazówki, w jaki sposób należy rozwiązać problem. Z dużym zaangażowaniem włączali się w dyskusje na temat oświaty i wychowania. Na koniec warto przytoczyć słowa księdza Michała Klepacza: „... należy walczyć z szablonową jednostronnością szkół, czyli z tzw. uniformizmem, i dążyć do tego, by dla każdej kategorii uzdolnień stworzyć warunki rozwoju jednakowo pomyślne, ale właśnie dlatego nie jednakowe.

Taka właśnie selekcja doskonale się mieści w pojęciu jedności szkolnictwa, jedności, rozumianej jako antyteza przywilejów stanowych, które daje urodzenie i majątek"31.

${ }^{30}$ I. M o ś c i c k i, Rozporządzenie państwowe. O kwalifikacjach zawodowych wychowawczyń Przedszkoli. Rozporządzenie prezydenta Rzeczypospolitej z dnia 27 X 1933 r., KPD 1934, z. 11, s. $274-275$.

${ }^{31}$ M. K I e p a c z, Duchowieństwo wobec nowoczesnych prądów w szkole polskiej. Stan realizowania szkoły jednolitej w różnych krajach, KPD 1930, z. 1, s. 30. 